JON STEPHENSON has reported on the Afghanistan conflict since the US-led war began in 2001.

\section{Shades of gray: The Taliban} phenomenon

Taliban: The True Story of the World's Most Feared Guerrilla Fighters, by James Fergusson. London: Bantam. 2010, 310 pp. ISBN 978-0-593066-34-8 (hardback)

JJUST CAN'T understand the Americans,' an Afghan mullah tells British writer James Fergusson. 'What they are doing makes no sense-and if they go on as they are, the whole country will rise against them.'

The mullah - an educated, apolitical man, fluent in five languages-is hauled from his bed one night by US commandos. Beaten and dragged off to the notorious Bagram detention centre, he is later released, but is so outraged he joins the Taliban.

Fergusson's story of the mistreated mullah is one of many amassed in his 14 years of reporting on Afghanistan. With crystal-clear writing and first-rate analysis, he deploys such

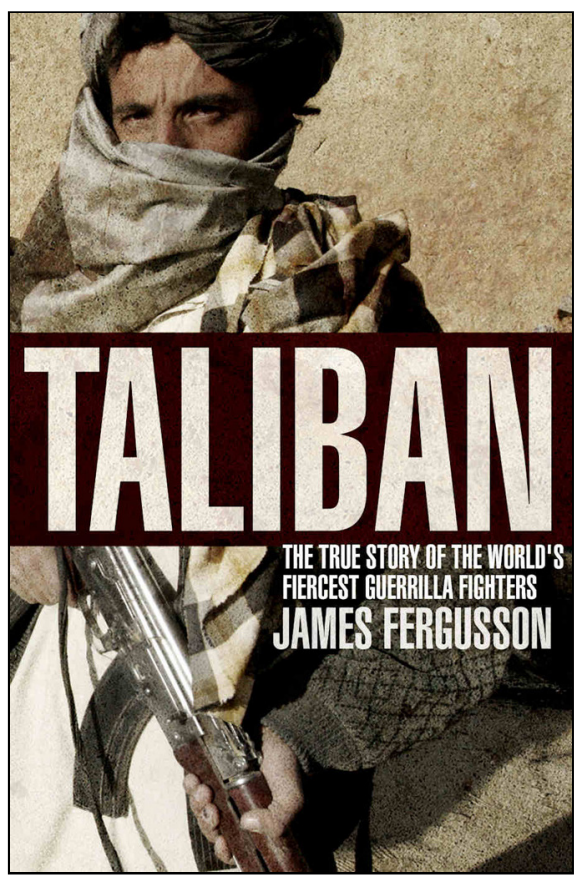

anecdotes to devastating effect in Taliban, subtitled The True Story of the World's Most Feared Guerrilla Fighters.

The topic is complex, but the book's structure is straightforward: the author first tells us who the Taliban are, how their movement arose, and what they want. He then asks if a deal with them is possible-one that would see Western troops leave Afghanistan in exchange for a guarantee the country would not revert to a terrorist safe-haven.

It is not only possible, he suggests, but desirable. The insurgency is growing; the US military strategy 
and Karzai administration are failing. We need a new plan, says Fergusson, and 'a negotiated settlement with the Taliban looks increasingly like the West's only way out of the mess'.

If the first principle of war is 'know your enemy' then, in Fergusson's eyes, the Americans have a lot to learn. The insurgents do not reject the West so much as the presence of infidel troops imposing Western political and social mores.

As a movement the Taliban have been 'relentlessly demonised'. They shared the same ideology as al Qaida, right? Wrong, says Fergusson. The relationship between Taliban leader Mullah Omar and Osama bin Laden was 90 percent about money.

They banned all education for women, right? Wrong again, says the author, whose nuanced explanation of the mullahs' mindset is fascinating. While their attitudes were not enlightened by Western standards, 'the Taliban were never quite the bearded bigots of popular Western imagination'.

They emerged as a force in the wake of the Soviet withdrawal from Afghanistan. But the Taliban-Pashtuns with a fierce tribal code who adhere to an austere form of Islam-existed long before the Bear got its paws burnt in the graveyard of empires.

When the Russians left Afghanistan in 1989, the mujahideen and warlords who had ousted them started battling each other. Butchers and bandits ruled the land. By 1994 the Taliban had had enough. They left their madrasahs and fought their way to power with two key goals: to impose security and Sharia.

'Many worse things have happened to Afghanistan than the Taliban government of 1996-2001,' says Fergusson. He does not brush the Taliban's dirt under the Afghan carpet - their treatment of the Hazara people was especially egregious - but argues they were for the most part misguided, not evil.

'It is not as if the West's track record in Afghanistan over the past nine years is anything to boast about,' he says. 'Lawlessness, corruption, poppies: the Taliban arguably dealt with all those better than we have since 2001.'

Today US-led forces are supporting a corrupt and ineffective regime that includes warlords and criminals the Taliban ousted - one in particular whose human rights record is far from distinguished. The idea that this regime's drug-addled and illiterate soldiers might 'stand up' to enable Western troops to 'draw down' sometime soon is rightly dismissed by the author as fanciful.

As the tale of the mistreated mullah reminds us, the way the US has prosecuted its counter-insurgency 
has only made things worse. Invading homes, detaining the wrong people, treating them with contempt-these are seen not only as an attack by infidels on Muslims but as a violation of the Pashtun code that cannot go unanswered.

This goes to the heart of the West's failure in Afghanistan. Introducing Western-style institutions, backing leaders who have lined their own pockets while ignoring their people, and the wayward air strikes that have killed and injured innocent Afghans have all generated anger and resentment.

But in a place where respect and religion are paramount it is the offences against honour and Islamboth real and perceived - that have arguably done the most damage, fanning the flames of an insurgency that refuses to be extinguished.

The bottom line? It's time to talk. As Fergusson says, all insurgencies end in negotiations. How can we know if the Taliban will moderate their ways and share power responsibly if we have not spoken to them?

Critics will argue that they have not learnt from their mistakes and cannot be trusted - that the Taliban will open the back door to Al Qaida as the West shuts the front door on its way out of Afghanistan. Others will oppose giving ground on the insurgents' desire to reintroduce Sharia.
The issues are complex, but it is worth remembering that the 2001 US-led invasion was justified as a response to terrorism, not the woeful predicament of Afghan women. If Western leaders want their troops to stay to curb Sharia they should say so, and be prepared to pay the price in blood and treasure.

As for Al Qaida, most assessments suggest its presence in Afghanistan is essentially at an end, and that the Taliban's goal is to end the occupation rather than advance bin Laden's goals or ideology. If an agreement to deny the terrorists sanctuary was broken, they could be countered more effectively by drones and special forces than by an army of occupation.

In any case, it seems increasingly clear that the occupiers have lost the battle for Pashtun hearts and minds, and as America's former Afghanistan commander General Stanley McChrystal once noted, 'If the people are against us we cannot be successful.'

Debates aside, this is a stunning book. Avoiding cliché or the black and white analysis all-too-common among Afghanistan observers, Fergusson illuminates many of the benighted nation's shades of grey. Meticulously researched and deeply thoughtful, it is explanatory journalism at its best. 
Copyright of Pacific Journalism Review is the property of Auckland University of Technology and its content may not be copied or emailed to multiple sites or posted to a listserv without the copyright holder's express written permission. However, users may print, download, or email articles for individual use.

http://www.aut.ac.nz/depts/commstud/journ/pjrsubs.shtml 